\title{
Effects of rumen-protected Capsicum oleoresin on productivity and responses to a glucose tolerance test in lactating dairy cows
}

\author{
J. Oh, ${ }^{*}$ M. Harper, ${ }^{*}$ F. Giallongo, ${ }^{*}$ D. M. Bravo, † E. H. Wall, $†$ and A. N. Hristov*1 \\ *Department of Animal Science, The Pennsylvania State University, University Park 16802 \\ †Pancosma S.A., CH-1218 Geneva, Switzerland
}

\begin{abstract}
The objective of this experiment was to investigate the effects of rumen-protected Capsicum oleoresin (RPC) supplementation on feed intake, milk yield and composition, nutrient utilization, fecal microbial ecology, and responses to a glucose tolerance test in lactating dairy cows. Nine multiparous Holstein cows were used in a replicated $3 \times 3$ Latin square design balanced for residual effects with three 28-d periods. Each period consisted of $14 \mathrm{~d}$ for adaptation and $14 \mathrm{~d}$ for data collection and sampling. Treatments were 0 (control), 100, and $200 \mathrm{mg}$ of RPC/cow per day. They were mixed with a small portion of the total mixed ration and top-dressed. Glucose tolerance test was conducted once during each experimental period by intravenous administration of glucose at a rate of $0.3 \mathrm{~g} / \mathrm{kg}$ of body weight. Dry matter intake was not affected by RPC. Milk yield tended to increase for RPC treatments compared to the control. Feed efficiency was linearly increased by RPC supplementation. Concentrations of fat, true protein, and lactose in milk were not affected by RPC. Apparent total-tract digestibility of dry matter, organic matter, and crude protein was linearly increased, and fecal nitrogen excretion was linearly decreased by RPC supplementation. Rumen-protected Capsicum oleoresin did not affect the composition of fecal bacteria. Glucose concentration in serum was not affected by RPC supplementation post glucose challenge. However, compared to the control, RPC decreased serum insulin concentration at 5, 10, and 40 min post glucose challenge. The area under the insulin concentration curve was also decreased $25 \%$ by RPC. Concentration of nonesterified fatty acids and $\beta$-hydroxybutyrate in serum were not affected by RPC following glucose administration. In this study, RPC tended to increase milk production and increased feed efficiency in dairy cows. In addition, RPC decreased serum insulin concentration during the
\end{abstract}

Received June 27, 2016.

Accepted November 18, 2016.

${ }^{1}$ Corresponding author: anh13@psu.edu glucose tolerance test, but glucose concentration was not affected by treatment.

Key words: Capsicum oleoresin, insulin, milk production, dairy cow

\section{INTRODUCTION}

Capsicum oleoresin, an acetone or hexane extract from Capsicum fruits, has been studied as a modifier of ruminal fermentation in cattle (Calsamiglia et al., 2007). Capsaicin, the main active compound in Capsicum oleoresin, has a phenolic structure and has been shown to exhibit antimicrobial effects in the rumen and to modify rumen fermentation (Calsamiglia et al., 2007). In beef cattle studies, Capsicum oleoresin applied as a feed additive decreased acetate proportion and increased ammonia concentration (Fandiño et al., 2008; Rodríguez-Prado et al., 2012). Capsicum oleoresin, however, had no effect on rumen fermentation in dairy cows (Tager and Krause, 2011; Oh et al., 2015).

Recent studies with dairy cows suggested that Capsicum may exhibit physiological effects directly on the host animal. For example, abomasal infusion of Capsicum oleoresin increased a subtype of $\mathrm{T}$ lymphocytes related to adaptive immunity (Oh et al., 2013). In addition, dietary supplementation of Capsicum oleoresin increased serum BHB concentration and neutrophil counts with no effect on rumen fermentation (Oh et al., 2015). In studies with nonruminants, Capsicum or capsaicin has been investigated with regard to its physiological effects (Lee et al., 2013a; Liu et al., 2014; Srinivasan, 2016). The regulatory effects of capsaicin include changes in feed intake, digestive enzyme secretion, fat mobilization, and hormone regulation. Capsaicin treatment stimulated gastric emptying and decreased leptin levels, which resulted in higher food intake in humans and rats (McCann et al., 1988; Debreceni et al., 1999; Hsu and Yen, 2007). Capsaicin increased the activity of digestive enzymes such as lipase and trypsin in pancreatic homogenate of rats (Platel and Srinivasan, 2000). Dietary inclusion or topical administration of capsaicin reduced adipose tissue and increased blood free fatty 
acids (FA) in rats (Yoshioka et al., 2000; Lee et al., 2013b). In addition, capsaicin reportedly increased or decreased pancreatic hormones in rats and human subjects (Dömötör et al., 2006; Chaiyasit et al., 2009). In particular, insulin concentration in blood was decreased by capsaicin after an intravenous glucose challenge in rats (van de Wall et al., 2005, 2006). Because insulin has a pivotal role in glucose homeostasis and homeorhesis in dairy cows (Bell and Bauman, 1997), the effect of capsaicin on insulin secretion may increase glucose availability to the mammary gland and thus milk production in dairy cows.

Based on existing literature with nonruminants and our previous experiments, we hypothesized that Capsicum acts in the digestive tract postruminally and may positively affect feed intake, nutrient utilization, gut microbial ecology, fat mobilization, and hormone regulation in dairy cows. Thus, the objective of the experiment was to investigate the effects of rumen-protected Capsicum oleoresin (RPC) supplementation on feed intake, milk production and composition, total-tract digestibility, nitrogen excretion, fecal bacterial population, and responses during a glucose tolerance test (GTT) in lactating dairy cows.

\section{MATERIALS AND METHODS}

\section{Animals and Treatments}

The Pennsylvania State University Animal Care and Use Committee approved all procedures used in this experiment. The experiment was a replicated $3 \times 3$ Latin square design, balanced for residual effects, and it was conducted at the tie-stall barn of The Pennsylvania State University's Dairy Teaching and Research Center. The experiment involved 9 Holstein cows (milk yield, $47 \pm 5.7 \mathrm{~kg} / \mathrm{d}$; DIM, $100 \pm 9.1 \mathrm{~d}$; and BW, 665 $\pm 83.3 \mathrm{~kg}$, at the beginning of the experiment). Cows were grouped in squares based on parity and milk yield. Each period consisted of $28 \mathrm{~d}$ : $14 \mathrm{~d}$ for adaptation and $14 \mathrm{~d}$ for data collection including sampling. An immune challenge was conducted on d 24 in each experimental period, and data generated after the challenge, including intake, milk production, and acute phase immune responses are presented in our companion paper (Oh et al., 2017). Cows were fed once daily ad libitum targeting 5 to $10 \%$ refusals and had free access to fresh water. During feeding, RPC was mixed with a small amount of the TMR and top-dressed on the feed. Treatments in this experiment were 3 levels of RPC: $0 \mathrm{mg} / \mathrm{d}$ (control), $100 \mathrm{mg} / \mathrm{d}$ (C100), and $200 \mathrm{mg} / \mathrm{d}$ (C200). The RPC product used in the experiment was Nexulin (X50-7035; 15.5\% Capsicum oleoresin; $0.93 \%$ capsaicinoids; Pancosma, S. A., Geneva, Switzerland). The dose amounts were determined based on previous work in our laboratory (Oh et al., 2015). In a separate in situ test, ruminal DM disappearance rate of RPC ranged from 3.30 to $27.8 \%$ in 24 -h incubation (data not shown). All cows were fed the same basal TMR (Table 1). Intake, refusal weights, and milk production were recorded daily. Recombinant bST (500 mg, i.m., Posilac; Elanco Co., Greenfield, IN) was administered at the beginning and middle of each experimental period.

\section{Sampling and Analyses}

Weekly composite samples of the TMR and refusals were prepared from subsamples collected twice weekly. Forages and concentrate feeds were sampled weekly, and composite samples were made for each experimental period. Composite samples of the TMR, forages, and concentrates were stored frozen, oven-dried to constant weight $\left(65^{\circ} \mathrm{C}\right)$, and ground through a $1-\mathrm{mm}$ sieve before being analyzed for $\mathrm{CP}$ (AOAC International, 2000), NDF (Van Soest et al., 1991), ADF (AOAC International, 2000), ether extract (AOAC International, 2006), Ca (AOAC International, 2000), $\mathrm{P}$ (AOAC International, 2000), and estimated NFC (NRC, 2001) and $\mathrm{NE}_{\mathrm{L}}$ (NRC, 2001) by Cumberland Valley Analytical Services (Maugansville, MD). Fecal and TMR samples were incinerated for $4 \mathrm{~h}$ at $600^{\circ} \mathrm{C}$ for analysis of ash and OM. Fecal, urine, blood, and milk samples were collected during the last week of each experimental period (Figure 1). Fecal and urine samples were collected by stimulating defecation from the rectum and by massaging the vulva, respectively, at 1000, 1600, and $2200 \mathrm{~h}$ on d 20; 0400, 1300, and 1900 $\mathrm{h}$ on d 21; and 0100 and $0700 \mathrm{~h}$ on d 22. Fecal samples (approximately $300 \mathrm{~g}$ ) were oven-dried at $65^{\circ} \mathrm{C}$ in a forced-air oven for $48 \mathrm{~h}$. After drying, samples were ground through a 1-mm sieve (Wiley mill), composited on an equal weight basis per cow and period, and analyzed for OM (as indicated previously for feed samples) and NDF and ADF (Ankom A200 fiber analyzer; Ankom Technology, Macedon, NY; Van Soest et al., 1991). Heat-stable amylase (Ankom Technology) and sodium sulfite (Fisher Scientific, Waltham, MA) were used in the NDF procedure. Dried fecal samples were pulverized at $30 \mathrm{~Hz} / \mathrm{s}$ for $2 \mathrm{~min}$ in a Mixer Mill MM 200 (Retsch GmbH, Haan, Germany) and analyzed for CP $(\mathrm{N} \times 6.25)$ on a Costech ECS $4010 \mathrm{C} / \mathrm{N} / \mathrm{S}$ elemental analyzer (Costech Analytical Technologies Inc., Valencia, CA). Fecal and TMR samples were analyzed for indigestible NDF as an intrinsic digestibility marker to estimate apparent total-tract digestibility of nutrients according to Huhtanen et al. (1994), with the exception 
Table 1. Ingredient and chemical composition of the basal diet fed during the experiment

\begin{tabular}{|c|c|}
\hline Item & $\%$ of diet DM \\
\hline \multicolumn{2}{|l|}{ Ingredients } \\
\hline Corn silage $^{1}$ & 43.5 \\
\hline Haylage $^{2}$ & 12.0 \\
\hline Cottonseed, hulls & 3.2 \\
\hline Corn grain, ground & 6.0 \\
\hline Candy by-product meal ${ }^{3}$ & 6.5 \\
\hline Soybean seeds, whole heated ${ }^{4}$ & 8.65 \\
\hline Canola meal ${ }^{5}$ & 8.65 \\
\hline Molasses $^{6}$ & 3.5 \\
\hline Vitamin and mineral premix ${ }^{7}$ & 3.0 \\
\hline SoyPLUS $^{8}$ & 5.0 \\
\hline \multicolumn{2}{|c|}{ Composition, ${ }^{9} \%$ of DM (or as indicated) } \\
\hline $\mathrm{CP}^{9}$ & 16.1 \\
\hline $\mathrm{RDP}^{10}$ & 9.8 \\
\hline RUP $^{10}$ & 6.9 \\
\hline $\mathrm{NDF}^{9}$ & 30.9 \\
\hline $\mathrm{ADF}^{9}$ & 23.2 \\
\hline $\mathrm{NE}_{\mathrm{L}}, \mathrm{Mcal} / \mathrm{kg}^{9}$ & 1.69 \\
\hline $\mathrm{Ca}^{9}$ & $\begin{array}{l}1.03 \\
1.02\end{array}$ \\
\hline $\mathrm{P}^{9}$ & 0.39 \\
\hline $\mathrm{NFC}^{10}$ & 45.2 \\
\hline Average $\mathrm{NE}_{\mathrm{L}}$ balance ${ }_{i 1}^{11} \mathrm{Mcal} / \mathrm{d}$ & $(4.5,3.6,3.2)$ \\
\hline Average MP balance, ${ }^{11} \mathrm{~g} / \mathrm{d}$ & $(359,330,304)$ \\
\hline
\end{tabular}

${ }^{1}$ Corn silage was $46.5 \% \mathrm{DM}$ and contained (DM basis) $6.7 \% \mathrm{CP}, 32.4 \%$ $\mathrm{NDF}$, and $42.7 \%$ starch.

${ }^{2}$ Haylage was $58.0 \% \mathrm{DM}$ and contained (DM basis) $21.0 \% \mathrm{CP}$ and $43.7 \% \mathrm{NDF}$

${ }^{3}$ Candy by-product meal (Graybill Processing, Elizabethtown, PA) contained (DM basis) $16.9 \% \mathrm{CP}$ and $26.7 \% \mathrm{NDF}$.

${ }^{4}$ Soybean seeds contained (DM basis) $40.0 \% \mathrm{CP}$.

${ }^{5}$ Canola meal contained (DM basis) $40.9 \% \mathrm{CP}$.

${ }^{6}$ Molasses (Westway Feed Products, Tomball, TX) contained (DM basis) $3.9 \% \mathrm{CP}$ and $66 \%$ total sugar.

${ }^{7}$ The premix (Cargill Animal Nutrition, Cargill Inc., Roaring Spring, PA) contained (\%, as-is basis) trace mineral mix, 0.86; $\mathrm{MgO}(56 \%$ $\mathrm{Mg}$ ), 8.0; $\mathrm{NaCl}, 6.4$; vitamin ADE premix (Cargill Animal Nutrition, Cargill Inc.), 0.48; limestone, 37.2; selenium premix (Cargill Animal Nutrition, Cargill Inc.), 0.07; and dry corn distillers grains with solubles, 46.7. Ca, 14.1\%; P, 0.39\%; Mg, 4.59\%; K, 0.44\%; S, 0.39\%; Se, $6.91 \mathrm{mg} / \mathrm{kg} ; \mathrm{Cu}, 362 \mathrm{mg} / \mathrm{kg}$; Zn, 1,085 mg/kg; Fe, $186 \mathrm{mg} / \mathrm{kg}$; vitamin A, 276,717 IU/kg; vitamin D, 75,000 IU/kg; and vitamin E, 1,983 IU/ $\mathrm{kg}$.

${ }^{8}$ SoyPLUS (West Central Cooperative, Ralston, IA) contained (DM basis) $47.2 \% \mathrm{CP}$.

${ }^{9}$ Values calculated using the chemical analysis (Cumberland Valley Analytical Services Inc., Maugansville, MD) of the ingredients of the diet.

${ }^{10}$ Estimated by NRC (2001).

${ }^{11}$ Estimated based on NRC (2001) using actual DMI, milk yield, milk composition, and BW of the cows throughout the experiment. Results are given as (control, C100, and C200), respectively. Treatments were 0, 100, or $200 \mathrm{mg} / \mathrm{d}$ of rumen-protected Capsicum oleoresin for control, C100, and C200, respectively.

of $25-\mu \mathrm{m}$ pore size filter bags (Ankom Technology) being used. Urine samples were acidified $(\mathrm{pH}<3)$ using 2 $M \mathrm{H}_{2} \mathrm{SO}_{4}$ (pH was verified using litmus paper), diluted 1:10 with distilled water, composited on an equal volume basis per cow and period, and stored frozen at $-20^{\circ} \mathrm{C}$. Urine samples were analyzed for $\mathrm{N}$ on a Costech
ECS $4010 \mathrm{C} / \mathrm{N} / \mathrm{S}$ elemental analyzer (Costech Analytical Technologies Inc.), urea N (Stanbio Urea Nitrogen Kit 580; Stanbio Laboratory Inc., San Antonio, TX), allantoin (Chen et al., 1992), uric acid (Stanbio Uric Acid kit 1045; Stanbio Laboratory Inc.), and creatinine (Stanbio Creatinine Kit 0400; Stanbio Laboratory Inc.). Urinary creatinine concentration was used for estimation of daily volume of excreted urine. Creatinine was assumed to be excreted at a rate of $29 \mathrm{mg} / \mathrm{kg}$ of BW (Hristov et al., 2011). Excretion of total N, urinary urea $\mathrm{N}$, and purine derivatives (PD; allantoin and uric acid) was calculated using estimated urine output. Fresh fecal samples were composited on an equal wet-weight basis by cow and experimental period and frozen immediately at $-20^{\circ} \mathrm{C}$. These samples were analyzed for bacterial population diversity by MR DNA (Molecular Research, Shallowater, TX) as described in Oh et al. (2015). In period 1 of the study, fecal and urine samples were collected following LPS challenge (see Oh et al., 2017). In periods 2 and 3, samples were collected before the LPS challenge. As DMI decreased significantly following LPS challenge in period 1, digestibility and urine data from periods 2 and 3 only are presented here.

Milk samples for composition analyses (fat, protein, lactose, SCC, MUN) were collected on d 20 during each experimental period (afternoon/evening and morning milkings) and submitted to Dairy One laboratory for analysis (Pennsylvania DHIA, University Park, PA). Milk composition was analyzed using infrared spectroscopy (MilkoScan 4000; Foss Electric, Hillerød, Denmark), and data were weighted for the corresponding afternoon/evening and morning milk yield.

Catheters (14-gauge $\times 13 \mathrm{~cm}$, MILA International Inc., Erlanger, KY) were inserted with an extension set into the jugular vein of all cows on the day before GTT. Catheters were flushed with $8 \mathrm{~mL}$ of heparinized saline $(10 \mathrm{IU} / \mathrm{mL})$ every $6 \mathrm{~h}$ and during blood sampling. Feeding was suspended for $12 \mathrm{~h}$ before the glucose challenge, but cows had access to water. Glucose $(50 \%$ D-glucose, Nova-Tech Inc., Grand Island, $\mathrm{NE}$ ) was administered intravenously at $0.3 \mathrm{~g} / \mathrm{kg}$ of BW within 3 min with a $60-\mathrm{mL}$ syringe. The dose of glucose was determined based on previous studies with dairy cows (Pires et al., 2007; Zachut et al., 2013). The GTT was performed once during the last week of each experimental period (Figure 1). Blood samples were collected from the jugular catheters at 0 (before glucose infusion), 5, 10, 15, 20, 30, 40, 50, 65, 80, and 110 min relative to glucose administration. Whole blood samples were collected into vacuumed tubes containing silica clot activator (SST Tube; BD Biosciences, Franklin Lakes, NJ), placed at room temperature for $1 \mathrm{~h}$ to allow clotting, and centrifuged at 3,000 $\times g$ at 
room temperature for 15 min to separate blood serum. Serum samples were kept frozen in a $-80^{\circ} \mathrm{C}$ freezer until analyses for glucose, insulin, nonesterified fatty acids (NEFA), BHB, and leptin. Samples from all time points were used for all the analyses except $\mathrm{BHB}$, which was analyzed only at 0,30 , and 65 min post glucose challenge. Serum glucose concentration was analyzed by a chemistry analyzer (VetTest Chemistry Analyzer, Idexx Laboratories, Inc., Westbrook, ME). A radioimmunoassay kit (PI-12K, EMD Millipore, Billerica, MA) was used for insulin analysis. The specificity for bovine insulin in the assay kit was $90 \%$ as suggested in the manufacturer's manual. Recovery tests were conducted to correct the underestimation of insulin concentration. The minimum detection level of insulin in the kit was $1.611 \mu \mathrm{U} / \mathrm{mL}$. An enzymatic colorimetric method [NEFA-HR(2), Wako Diagnostics, Mountain View, CA] was used for NEFA, and inter- and intra-assay precision of this method was 0.61 to $0.75 \% \mathrm{CV}$ and 0.75 to $4.91 \%$ $\mathrm{CV}$, respectively. The minimum detectable level of the method was $0.0014 \mu \mathrm{mol} / \mathrm{L}$ (oleic acid equivalent). A biochemistry analyzer (Cobas 6000; Roche, Germany) was used for BHB analysis. Leptin concentration in serum was analyzed using radioimmunoassay (XL-85K, EMD Millipore). Inter- and intra-assay precision of the leptin kit was 6.5 to $8.7 \% \mathrm{CV}$ and 2.8 to $3.6 \% \mathrm{CV}$, respectively. The minimum detection level of leptin in the kit was $0.801 \mathrm{ng} / \mathrm{mL}$.

\section{Calculations and Statistical Analysis}

Microsoft EXCEL (Microsoft Corp., Seattle, WA) was used to fit exponential curves for glucose and in- sulin data using the following equation (Pires et al., 2007):

$$
\mathrm{F}(t)=A \times \mathrm{e}^{(-\mathrm{k} \times t)}
$$

where $\mathrm{F}(t)$ is the concentration at time $t ; A$ is the maximum concentration; $t$ is the time after the glucose challenge; and $\mathrm{k}$ is the regression coefficient. Clearance rate $(\mathbf{C R})$, time to half-maximal concentration $\left(\mathrm{T}_{1 / 2}\right)$, and time to reach basal concentration $\left(\mathrm{T}_{\text {basal }}\right)$ were calculated by the following equations:

$$
\begin{gathered}
\mathrm{CR}(\% / \mathrm{min})=\{[\ln (\mathrm{ta})-\ln (\mathrm{tb})] \\
\div(\mathrm{tb}-\mathrm{ta})\} \times 100, \\
T_{1 / 2}=\{[\ln (2)] \div \mathrm{CR}\} \times 100, \\
T_{\text {basal }}=\{[\ln (\mathrm{ta})-\ln (\mathrm{tb})] \div \mathrm{CR}\} \times 100,
\end{gathered}
$$

where ta is the concentration at time $a$, and tb is the concentration at time $b$.

The trapezoidal method was used for calculating the area under the glucose and insulin concentration curve (AUC) post glucose challenge using the positive incremental area method (Cardoso et al., 2011). Concentrations at $0 \mathrm{~h}$ (before the glucose challenge) were used as baseline concentrations.

All data were analyzed using the MIXED procedure of SAS 9.3 (2003; SAS Institute Inc., Cary, NC). Milk yield, DMI, and estimated feed efficiency data for 9 d after adaptation period of each experimental period were used in the statistical analysis. The averaged milk

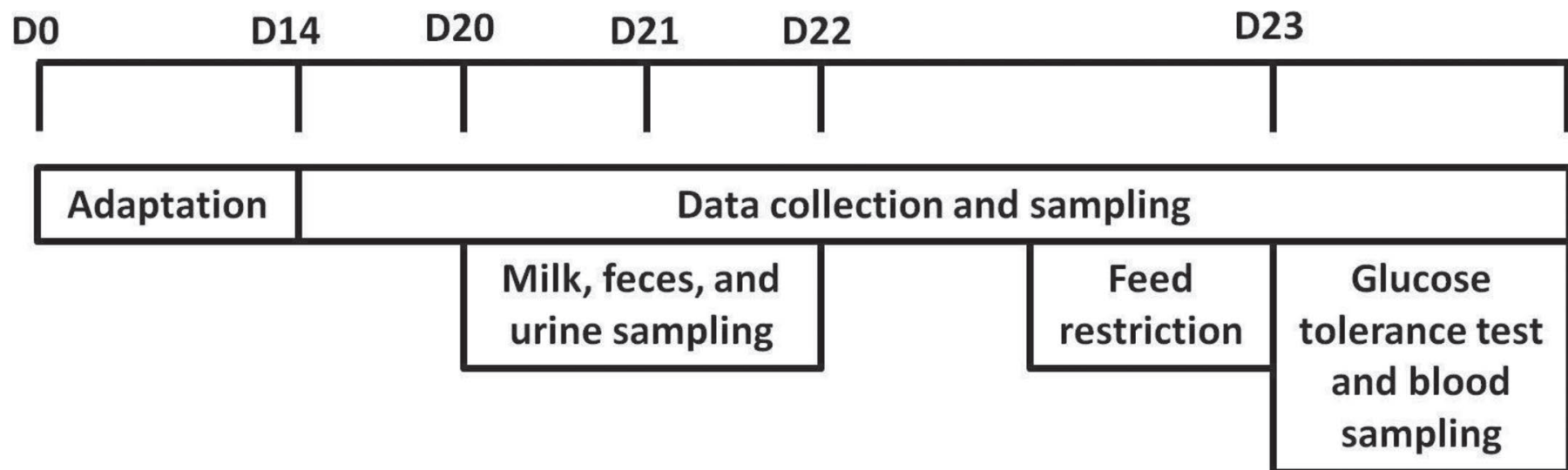

Figure 1. Schematic diagram of the experiment. Milk samples were collected on afternoon/evening and morning milkings on D (day of experimental period) 20. Fecal and urine samples were collected 8 times: D20 at 1000, 1600, and 2200 h; D21 at 0400, 1300 , and 1900 h; D22 at 0100 and $0700 \mathrm{~h}$. Catheters for glucose tolerance test were inserted on D22, and cows were restricted on feed from $2100 \mathrm{~h}$ on D22. Glucose challenge occurred at $0900 \mathrm{~h}$ on D23 and was followed by blood sampling. 
yield and milk composition data were used to calculate yields of milk fat, true protein, lactose, and ECM. Data were tested for normality using the UNIVARIATE procedure of SAS. Log-transformed data were analyzed when the W statistic of the Shapiro-Wilk test was < 0.05 .

Nutrient intake, digestibility, urinary and fecal $\mathrm{N}$ excretions, fecal bacterial population, milk composition, and GTT data (glucose, insulin, NEFA, BHB, and leptin) for each sampling time post glucose administration including AUC, peak and basal concentration, CR, $\mathrm{T}_{1 / 2}$, and $\mathrm{T}_{\text {basal }}$ were analyzed by ANOVA Latin square. The model used was as follows:

$$
Y_{i j k l}=\mu+\mathrm{S}_{i}+\mathrm{C}(\mathrm{S})_{i j}+\mathrm{P}_{k}+\mathrm{T}_{l}+\mathrm{PT}_{k l}+\mathrm{e}_{i j k l}
$$

where $Y_{i j k l}$ is the dependent variable, $\mu$ is the overall mean, $\mathrm{S}_{i}$ is the square, $\mathrm{C}(\mathrm{S})_{i j}$ is the cow within square, $\mathrm{P}_{k}$ is the $k$ th period, $\mathrm{T}_{l}$ is the $l$ th treatment, and $\mathrm{PT}_{k l}$ is the period $\times$ treatment effect with the error term $\mathrm{e}_{i j k l}$. Square and cow within square were random effects, and all others were fixed.

Dry matter intake, milk yield, feed efficiency, and GTT data (glucose, insulin, NEFA, BHB, and leptin) for all the sampling times were analyzed as repeated measures assuming an $\mathrm{AR}(1)$ covariance structure. The model used was as follows:

$$
\begin{aligned}
Y_{i j k l m}= & \mu+\mathrm{S}_{i}+\mathrm{C}(\mathrm{S})_{i j}+\mathrm{P}_{k}+\mathrm{T}_{l}+\mathrm{D}_{m} \\
& +\mathrm{PT}_{k l}+\mathrm{TD}_{l m}+\mathrm{e}_{i j k l m},
\end{aligned}
$$

where $\mathrm{Y}_{i j k l m}$ is the dependent variable, $\mu$ is the overall mean, $\mathrm{S}_{i}$ is the square, $\mathrm{C}(\mathrm{S})_{i j}$ is the cow within square, $\mathrm{P}_{k}$ is the $k$ th period, $\mathrm{T}_{l}$ is the $l$ th treatment, $\mathrm{D}_{m}$ is the time effect, $\mathrm{PT}_{k l}$ is the period $\times$ treatment interaction, and $\mathrm{TD}_{l m}$ is the treatment $\times$ time interaction with the error term $\mathrm{e}_{i j k l m}$. Square and cow within square were random effects, and all others were fixed.

Orthogonal contrasts were used to evaluate RPC treatments versus control and linear effect of RPC supplementation. Statistical differences were considered significant at $P<0.05$ and a trend at $0.05 \leq P<0.10$. Data are presented as least squares means.

\section{RESULTS}

The basal diet used in this experiment was formulated to meet $\mathrm{NE}_{\mathrm{L}}$ and $\mathrm{MP}$ requirements of cows milking $45 \mathrm{~kg} / \mathrm{d}$ (Table 1). The experimental diet supplied $\mathrm{NE}_{\mathrm{L}}$ and MP in excess of cow requirements (NRC, 2001). Supplementation of RPC on the basal diet did not affect DMI (Table 2). Milk yield tended to be increased $(P=0.06)$ by RPC. A linear increase $(P<0.01)$ in feed efficiency was observed with RPC. Milk fat, true

Table 2. Effect of rumen-protected Capsicum oleoresin on milk yield and composition in dairy cows

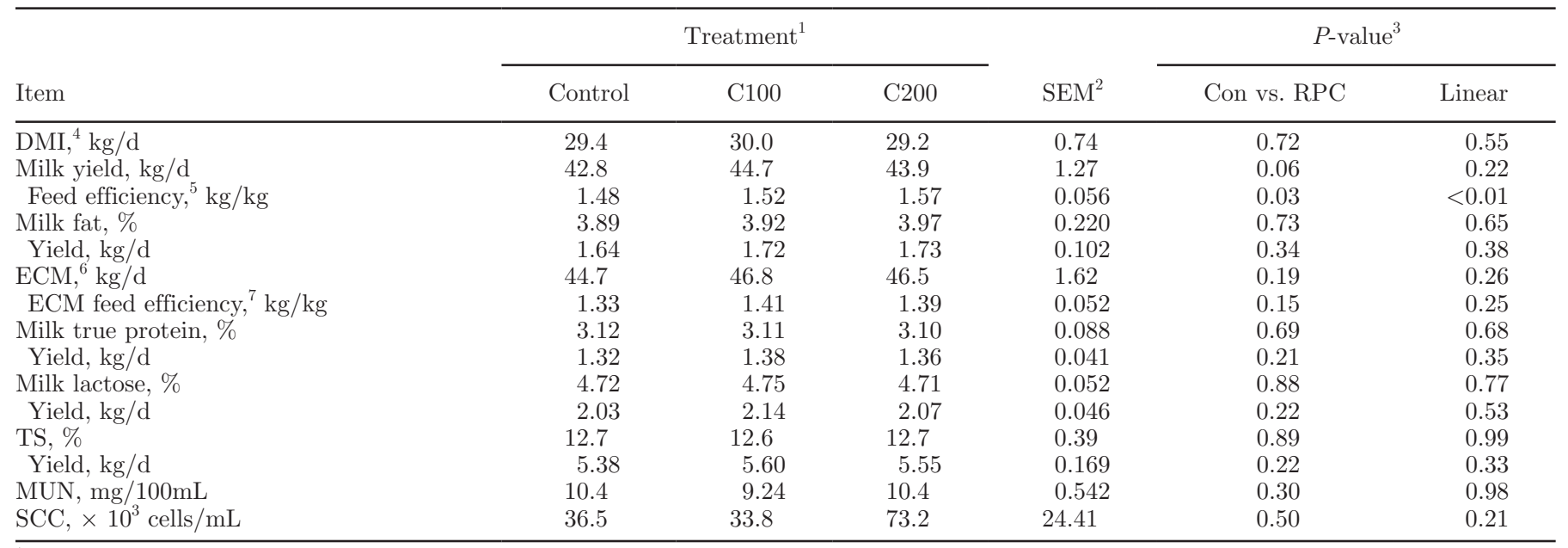

${ }^{1}$ Control $=0 \mathrm{mg} / \mathrm{d}$ rumen-protected Capsicum oleoresin (RPC); C100 = $100 \mathrm{mg} / \mathrm{d}$ RPC; C200 = $200 \mathrm{mg} / \mathrm{d}$ RPC.

${ }^{2}$ Highest SEM shown; $\mathrm{n}=215$ for DMI, $\mathrm{n}=202$ for milk yield and feed efficiency, $\mathrm{n}=24$ for all other variables ( $\mathrm{n}$ represents number of observations used in the statistical analysis).

${ }^{3}$ Con vs. RPC $=$ control vs. RPC treatment; Linear $=$ linear effect of RPC.

${ }^{4}$ Control vs. C100, $P=0.23$; Control vs. C200, $P=0.54$.

${ }^{5}$ Milk yield $\div$ DMI.

${ }^{6}$ Energy-corrected milk $(\mathrm{kg} / \mathrm{d})=$ milk production $(\mathrm{kg} / \mathrm{d}) \times(383 \times \%$ fat $+242 \times \%$ true protein $+165.4 \times \%$ lactose +20.7$) \div 3,140($ Sjaunja et al., 1990).

${ }^{7} \mathrm{ECM} \div$ DMI. 
Table 3. Effect of rumen-protected Capsicum oleoresin on total-tract digestibility of nutrients in dairy cows ${ }^{1}$

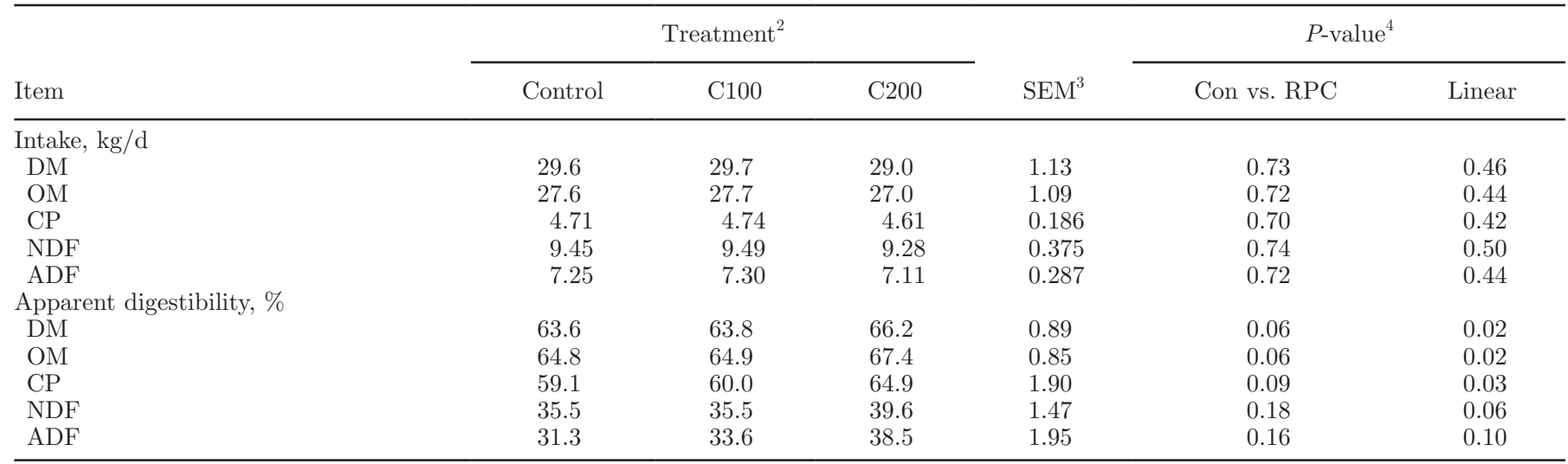

${ }^{1}$ Digestibility data were collected in experimental periods 2 and 3 only.

${ }^{2}$ Control $=0 \mathrm{mg} / \mathrm{d}$ rumen-protected Capsicum oleoresin (RPC); C100 = $100 \mathrm{mg} / \mathrm{d}$ RPC; C200 = $200 \mathrm{mg} / \mathrm{d}$ RPC.

${ }^{3}$ Highest SEM shown; $\mathrm{n}=18$ for all variables (n represents number of observations used in the statistical analysis).

${ }^{4}$ Con vs. $\mathrm{RPC}=$ control vs. $\mathrm{RPC}$ treatment; Linear $=$ linear effect of RPC.

protein, and lactose concentrations and TS, ECM yield, ECM feed efficiency, MUN, and SCC were not affected by treatment.

Total-tract digestibility of $\mathrm{DM}, \mathrm{OM}$, and $\mathrm{CP}$ was linearly increased $(P \leq 0.03)$, whereas that of NDF and ADF tended to be linearly increased $(P \leq 0.10)$ with RPC compared to the control (Table 3). Although excretion of urine $\mathrm{N}$ and urinary urea $\mathrm{N}$ was similar among treatments, fecal $\mathrm{N}$ excretion and total excreta $\mathrm{N}$ tended to be linearly decreased $(P \leq 0.07)$ by RPC (Table 4). The proportion of fecal $\mathrm{N}$ excreted to $\mathrm{N}$ intake was linearly decreased $(P=0.03)$ by RPC. Uric acid, allantoin, and total urinary PD excretions were not affected by treatment.

The predominant genera ( $>10 \%$ of total sequences) of fecal bacteria in this experiment were Ruminococcus, Bifidobacterium, Barnesiella, and Fecalibacterium (Table 5). The relative abundance of fecal bacteria was not affected by RPC.

Serum glucose concentration peaked at $5 \mathrm{~min}$ and returned to the basal level at $80 \mathrm{~min}$ after glucose challenge (Figure 2). Glucose concentration was not affected by RPC at all sampling times, except trends for decrease $(P \leq 0.07)$ at 40 and 110 min post glucose

Table 4. Effect of rumen-protected Capsicum oleoresin on nitrogen utilization in dairy cows ${ }^{1}$

\begin{tabular}{|c|c|c|c|c|c|c|}
\hline Item & \multicolumn{3}{|c|}{ Treatment $^{2}$} & $\mathrm{SEM}^{3}$ & \multicolumn{2}{|c|}{$P$-value ${ }^{4}$} \\
\hline Urine N & 154 & 145 & 154 & 15.7 & 0.69 & 1.00 \\
\hline Urine urea $\mathrm{N}$ & 99.6 & 89.7 & 106 & 5.63 & 0.72 & 0.36 \\
\hline Fecal N & 303 & 298 & 260 & 20.9 & 0.13 & 0.06 \\
\hline Urine $\mathrm{N}$ & 21.7 & 19.7 & 20.6 & 2.89 & 0.51 & 0.68 \\
\hline Fecal N & 40.9 & 40.0 & 35.1 & 1.89 & 0.09 & 0.03 \\
\hline Total excreta $\mathrm{N}$ & 61.8 & 59.9 & 56.0 & 1.65 & 0.16 & 0.09 \\
\hline Creatinine, $\mathrm{m} M$ & 7.25 & 8.33 & 8.63 & 0.626 & 0.07 & 0.09 \\
\hline \multicolumn{7}{|c|}{ Urinary $\mathrm{PD}^{5}$ excretion, $\mathrm{mmol} / \mathrm{d}$} \\
\hline Allantoin & 452 & 431 & 472 & 35.2 & 1.00 & 0.69 \\
\hline Uric acid & 68.8 & 52.3 & 64.5 & 6.43 & 0.12 & 0.52 \\
\hline
\end{tabular}

${ }^{1}$ Urine data were collected in experimental periods 2 and 3 only.

${ }^{2}$ Control $=0 \mathrm{mg} / \mathrm{d}$ rumen-protected Capsicum oleoresin (RPC); C100 = $100 \mathrm{mg} / \mathrm{d}$ RPC; C200 = $200 \mathrm{mg} / \mathrm{d}$ RPC.

${ }^{3}$ Highest SEM shown; $\mathrm{n}=18$ for all variables (n represents number of observations used in the statistical analysis).

${ }^{4}$ Con vs. RPC $=$ control vs. RPC treatment; Linear $=$ linear effect of RPC.

${ }^{5} \mathrm{PD}=$ purine derivatives. 
challenge. Glucose concentration was also not different among treatments when analyzed as repeated measure across all sampling times (Table 6). Basal and peak levels, $\mathrm{CR}, \mathrm{T}_{1 / 2}, \mathrm{~T}_{\text {basal }}$, and AUC of glucose also did not differ among treatments. Insulin concentration peaked at $10 \mathrm{~min}$ for the control and at $5 \mathrm{~min}$ for $\mathrm{C} 100$ and C200, and returned to the basal level at 65 min after glucose administration (Figure 3). Serum insulin concentration was decreased $(P \leq 0.04)$ at 5,10 , and 40 min and tended to be decreased $(P \leq 0.08)$ at 30 and 50 min by RPC compared to the control. Basal insulin concentration, $\mathrm{CR}, \mathrm{T}_{1 / 2}$, and $\mathrm{T}_{\text {basal }}$ were not affected by the treatment (Table 6). However, peak concentration of insulin tended to decrease $(P=0.07)$ and the insulin AUC decreased $(P=0.04)$ with RPC by an average of $25 \%$ compared to the control. Serum NEFA concentration decreased following glucose challenge, reached the lowest levels at 30 or $40 \mathrm{~min}$, and returned to the basal level at $120 \mathrm{~min}$ (Figure 4). Overall, NEFA was not affected by RPC during GTT, except linear increases $(P=0.03)$ at 65 and $80 \mathrm{~min}$. We also observed no effect of RPC on NEFA concentration during GTT when data were analyzed as repeated measure (Table 7). Serum concentration of BHB was not affected by RPC, although numerical increases $(P \geq 0.15)$ were observed for RPC before and after glucose challenge (Table 7). Serum BHB concentration in this experiment was below the level for subclinical ketosis $(1,200$ to $2,900 \mu \mathrm{mol} / \mathrm{L}$; Oetzel, 2004). Leptin concentration in serum started to increase at 10 or 15 min after glucose challenge (Figure 5). The control had a peak level of leptin at 30 min, whereas C100 and C200 peaked at 50 and $80 \mathrm{~min}$, respectively. Leptin concentration returned to the basal level at 110 min after glucose infusion for all the groups. Serum leptin concentration post glucose challenge tended to be linearly decreased $(P=0.08)$ by RPC when analyzed as repeated measure (Table 7). However, a treatment $\times$ period interaction $(P<$ 0.01 ) was observed for the leptin data. The interaction was caused by a variable response to treatment during the experimental periods. Thus, leptin data should be interpreted with caution.

\section{DISCUSSION}

The lack of effect of RPC on DMI in the current experiment is in accordance with previous studies with dairy cows (Tager and Krause, 2011; Oh et al., 2013, 2015). Supplementation of Capsicum through the feed or directly into the abomasum in dairy cows did not affect DMI, although Capsicum supplementation increased DMI and water consumption in studies with beef cattle (Cardozo et al., 2006; Rodríguez-Prado et al., 2012). This discrepancy between beef and dairy studies is probably a result of the amounts of Capsicum used in dairy cows being relatively smaller than those used in beef cattle as previously discussed by $\mathrm{Oh}$ et al. (2015).

Table 5. Effect of rumen-protected Capsicum oleoresin on relative abundance (as percentage ${ }^{1}$ of total sequences) of major fecal bacterial genera in dairy cows ${ }^{2}$

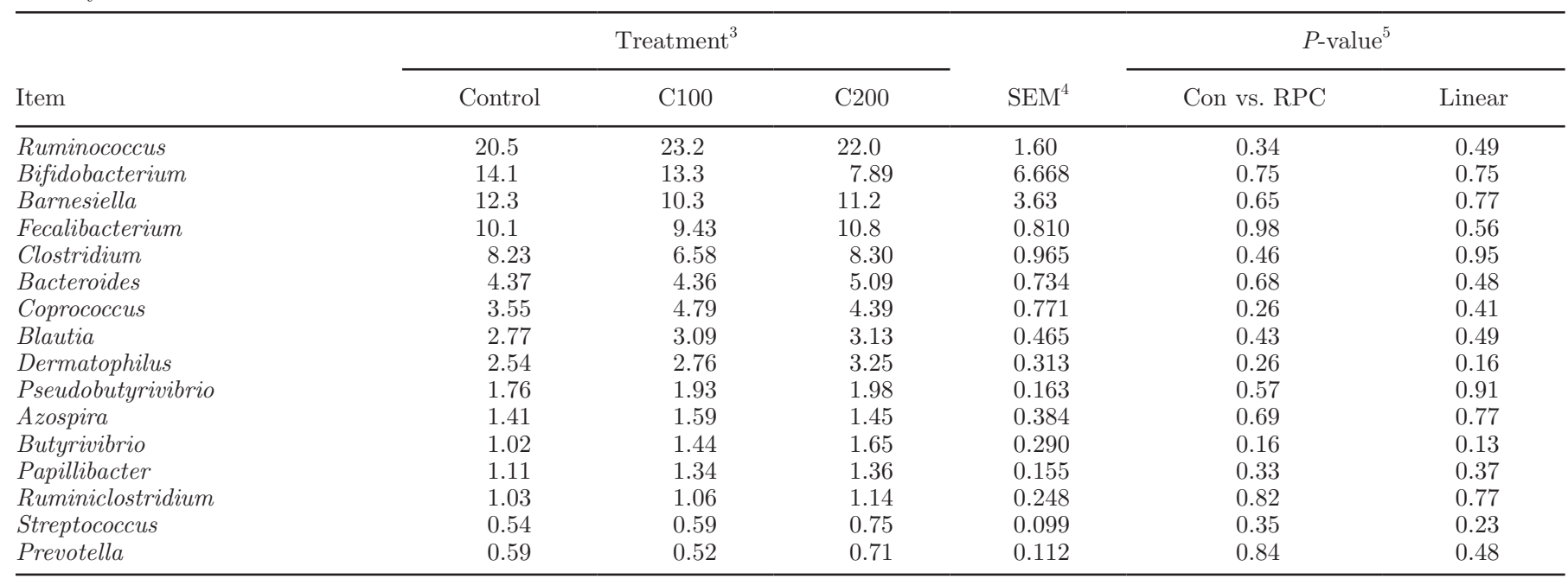

${ }^{1}$ The percentage represents the percentage of the total sequences analyzed within the sample.

${ }^{2}$ Data were collected in experimental periods 2 and 3 only.

${ }^{3}$ Control $=0 \mathrm{mg} / \mathrm{d}$ rumen-protected Capsicum oleoresin (RPC); C100 = $100 \mathrm{mg} / \mathrm{d}$ RPC; C200 = $200 \mathrm{mg} / \mathrm{d}$ RPC.

${ }^{4}$ Highest SEM shown; $\mathrm{n}=18$ for all variables ( $\mathrm{n}$ represents number of observations used in the statistical analysis).

${ }^{5}$ Con vs. $\mathrm{RPC}=$ control vs. RPC treatment; Linear $=$ linear effect of RPC. 
Table 6. Effect of rumen-protected Capsicum oleoresin on serum glucose and insulin concentration response to glucose tolerance test in dairy cows

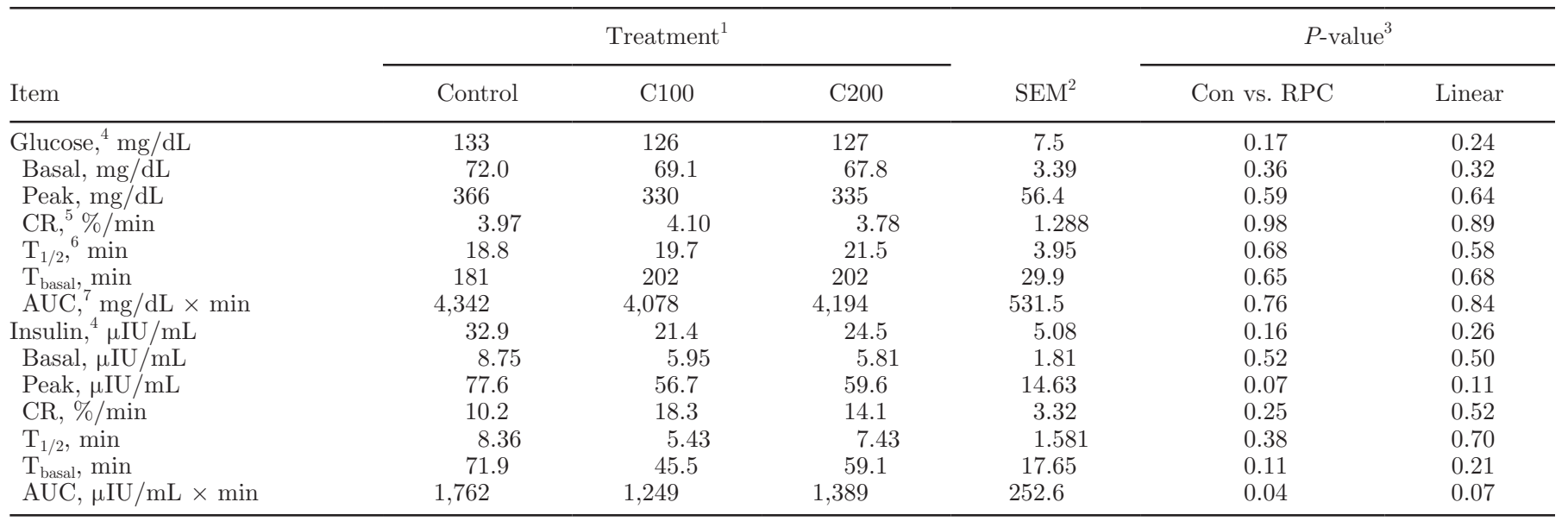

${ }^{1}$ Control $=0 \mathrm{mg} / \mathrm{d}$ rumen-protected Capsicum oleoresin $(\mathrm{RPC}) ; \mathrm{C} 100=100 \mathrm{mg} / \mathrm{d} \mathrm{RPC} ; \mathrm{C} 200=200 \mathrm{mg} / \mathrm{d}$ RPC.

${ }^{2}$ Highest SEM shown; $\mathrm{n}=249$ for glucose and insulin, $\mathrm{n}=23$ for all other variables ( $\mathrm{n}$ represents number of observations used in the statistical analysis).

${ }^{3}$ Con vs. $\mathrm{RPC}=$ control vs. RPC treatment; Linear $=$ linear effect of RPC.

${ }^{4}$ Data were analyzed as repeated measures.

${ }^{5} \mathrm{CR}=$ clearance rate

${ }^{6} \mathrm{~T}_{1 / 2}=$ half-life.

${ }^{7} \mathrm{AUC}=$ area under the curve

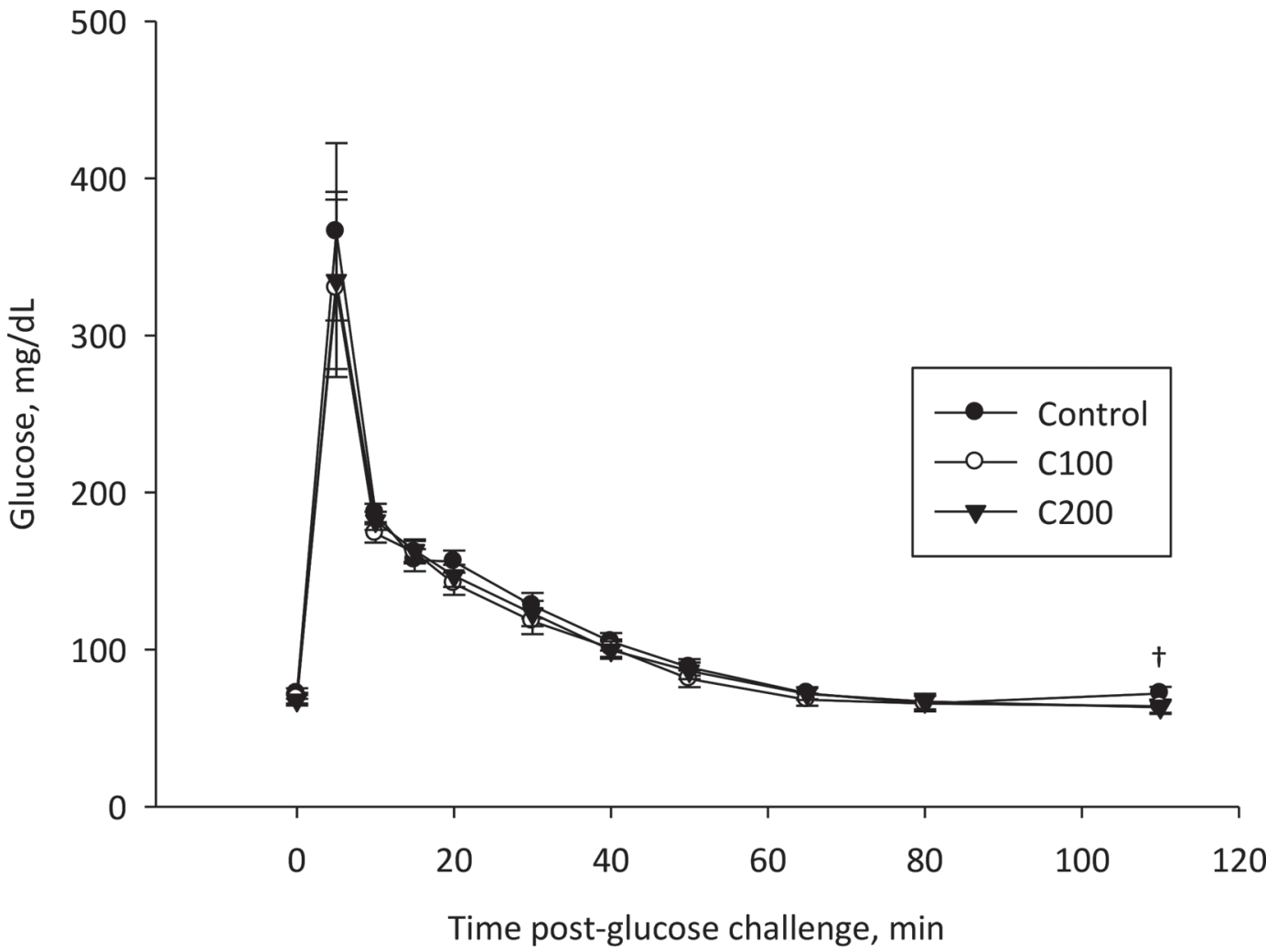

Figure 2. Effect of rumen-protected Capsicum oleoresin (RPC) on serum glucose concentration (mean \pm SE) following intravenous administration of glucose in dairy cows. Control $=0 \mathrm{mg} / \mathrm{d}$ RPC; C100 $=100 \mathrm{mg} / \mathrm{d}$ RPC; C200 = $200 \mathrm{mg} / \mathrm{d}$ RPC. Orthogonal contrast between control and treatments $(\mathrm{n}=23 ; \mathrm{n}$ represents number of observations used in the statistical analysis $), \uparrow P=0.07$ control vs. RPC. 
Total-tract digestibility in ruminants is affected by degradation and passage rates in the rumen and enzymatic digestion in the lower gut. We did not measure rumen fermentation parameters or the passage rate in the current experiment, but Tager and Krause (2011) and Oh et al. (2015) reported no effect of Capsicum on ruminal VFA and ammonia concentration, and no difference was observed in total PD excretion as an indicator of ruminal microbial synthesis among treatments in the current experiment. Although the major site for digestion of feed in ruminants is the rumen, contribution of the lower gut is not negligible and has been reported to be $35.3,21.2$, and $19.5 \%$ to total-tract digestibility for OM, cell wall, and starch, respectively, in a comprehensive review by Archimède et al. (1997). The increase in total-tract digestibility of dietary nutrients by RPC in the current experiment may be due to stimulatory effects of capsaicin on digestive enzymes in the lower gut. Dietary supplementation of capsaicin has been reported to increase secretion of enzymes such as lipase, amylase, trypsin, and chymotrypsin in the pancreas of rats (Platel and Srinivasan, 1996, 2000). Ramakrishna Rao et al. (2003) also found an increase of amylase activity in pancreas homogenate with cap- saicin administration. The linear decreases in fecal $\mathrm{N}$ excretion by RPC were in accordance with the totaltract digestibility data in the current experiment. Previous experiments with dairy cows, however, reported no effect of Capsicum oleoresin on total-tract digestibility of DM, OM, CP, NDF, and ADF and on fecal N excretion in dairy cows (Tager and Krause, 2011; Oh et al., 2015). In addition, supportive data such as secretion or activity of secreted intestinal digestive enzymes were not collected. It should also be pointed out that the digestibility data are from 6 cows only and should therefore be interpreted with caution.

Capsicum has been known to exhibit inhibitory effects on bacteria in the intestine as well as in the rumen (Cichewicz and Thorpe, 1996; Calsamiglia et al., 2007). The phenolic group of capsaicin may suppress the growth of bacteria by decreasing membrane stability because of its hydrophobicity (Burt, 2004). However, in vivo experiments with dairy cows showed no effect of Capsicum on intestinal bacteria. In a short-term (5-d) abomasal pulse-dose study, we reported that Capsicum treatment did not affect fecal bacterial populations in dairy cows (Oh et al., 2013). In the current experiment, dietary supplementation of RPC for a longer period (20

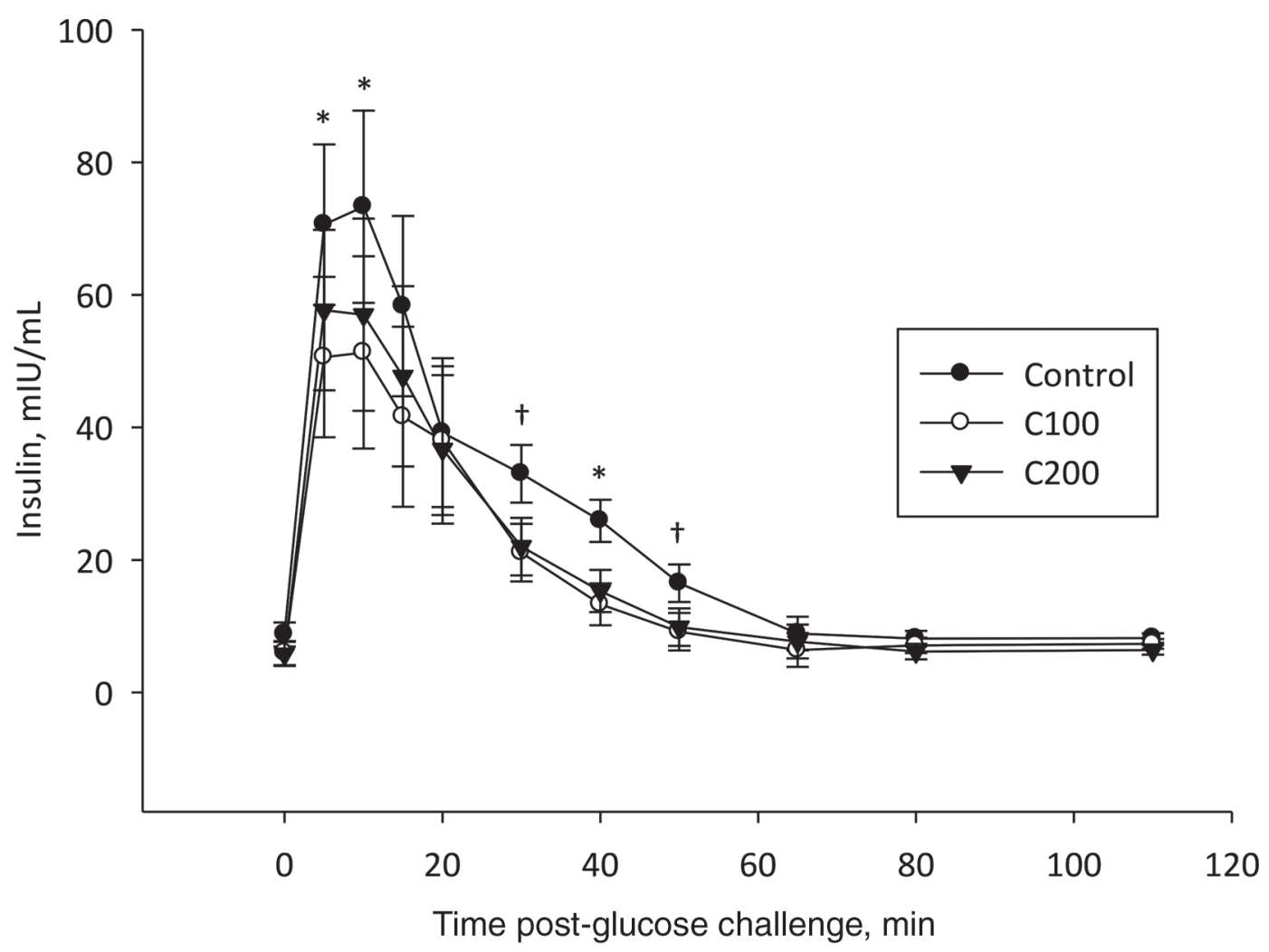

Figure 3. Effect of rumen-protected Capsicum oleoresin (RPC) on serum insulin concentration (mean \pm SE) following intravenous administration of glucose in dairy cows. Control $=0 \mathrm{mg} / \mathrm{d}$ RPC; C100 $=100 \mathrm{mg} / \mathrm{d}$ RPC; C200 $=200 \mathrm{mg} / \mathrm{d}$ RPC. Orthogonal contrast between control and treatments $\left(\mathrm{n}=23 ; \mathrm{n}\right.$ represents number of observations used in the statistical analysis), ${ }^{*} P \leq 0.05$ and $\dagger 0.05<P \leq 0.10$ control vs. RPC. 
Table 7. Effect of rumen-protected Capsicum oleoresin on concentration of nonesterified fatty acids (NEFA), BHB, and leptin in serum following glucose tolerance test in dairy cows

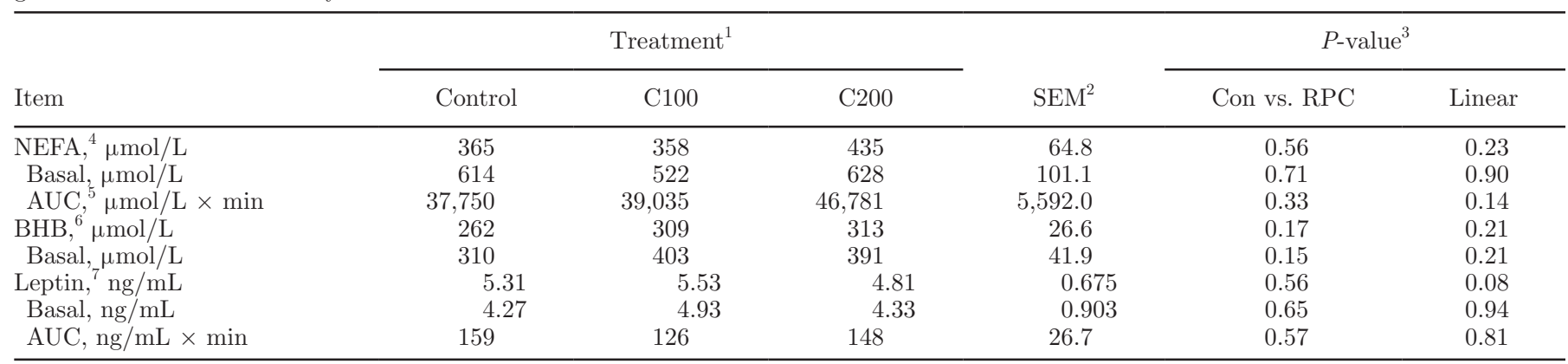

${ }^{1}$ Control $=0 \mathrm{mg} / \mathrm{d}$ rumen-protected Capsicum oleoresin (RPC); C100 = $100 \mathrm{mg} / \mathrm{d} \mathrm{RPC}$; $200=200 \mathrm{mg} / \mathrm{d}$ RPC.

${ }^{2}$ Highest SEM shown; $\mathrm{n}=255$ for NEFA, $\mathrm{n}=69$ for BHB, $\mathrm{n}=216$ for leptin, and $\mathrm{n}=23$ for all other variables ( $\mathrm{n}$ represents number of observations used in the statistical analysis).

${ }^{3}$ Con vs. $\mathrm{RPC}=$ control vs. $\mathrm{RPC}$ treatment; Linear $=$ linear effect of RPC.

${ }^{4}$ Oleic acid equivalent.

${ }^{5} \mathrm{AUC}=$ area under the curve.

${ }^{6} \mathrm{BHB}$ was measured only at 0,30 , and 65 min post-glucose challenge.

${ }^{7}$ Period $\times$ treatment, $P<0.01$.

d) also did not affect fecal bacterial populations of the cows.

Serum insulin concentration was decreased by RPC, but glucose concentration remained similar among treatments during GTT in the current experiment. Similar results were reported in rats with capsaicin (van de Wall et al., 2005, 2006). These authors observed lower insulin levels in rats neonatally treated with cap-

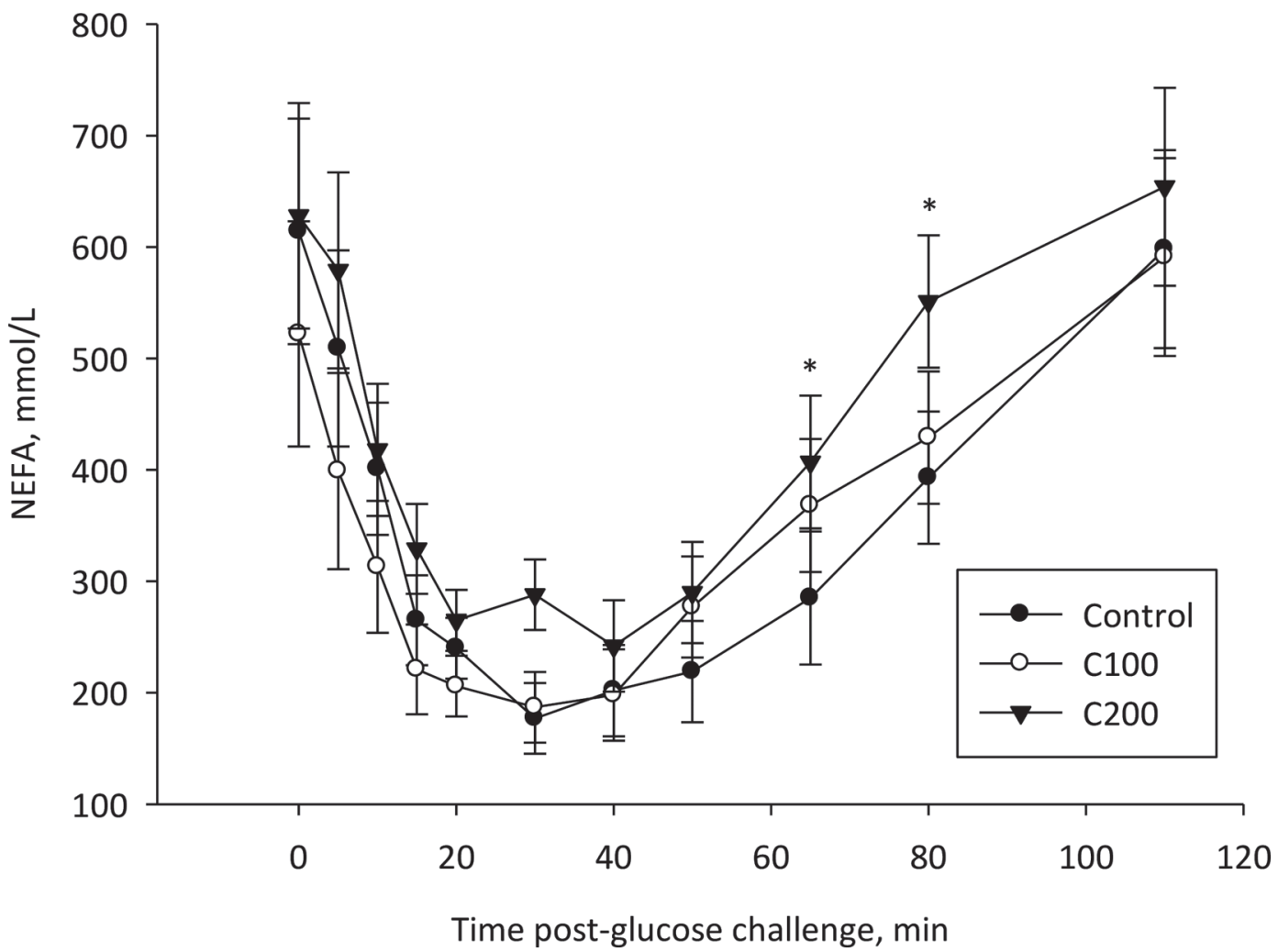

Figure 4. Effect of rumen-protected Capsicum oleoresin (RPC) on serum nonesterified fatty acid (NEFA) concentration (mean \pm SE) following intravenous administration of glucose in dairy cows. Control $=0 \mathrm{mg} / \mathrm{d}$ RPC; C100 $=100 \mathrm{mg} / \mathrm{d}$ RPC; C200 $=200 \mathrm{mg} / \mathrm{d}$ RPC. Orthogonal contrast between control and treatments $(\mathrm{n}=23 ; \mathrm{n}$ represents number of observations used in the statistical analysis), $* P \leq 0.05$ linear effect. 
saicin during intravenous GTT, whereas glucose was not affected by treatment. In human subjects, regular consumption of cayenne pepper containing 2,000 ppm capsaicin lowered hyperinsulinemia after meals, with no effect on glucose concentration in blood (Ahuja et al., 2006). The inhibitory effect of capsaicin on insulin might be exhibited via calcitonin gene-related peptide (CGRP), a neuropeptide produced in neurons, which is known to decrease insulin secretion from the pancreas (Pettersson and Ahrén, 1990; Tanaka et al., 2013). Demirbilek et al. (2004), for example, observed that subcutaneously administered capsaicin increased plasma CGRP concentration in rats. Oral administration of a red chili homogenate in human subjects also increased CGRP concentration in a dose-dependent manner (van Oosterhout et al., 2015). In the current experiment, RPC may have stimulated CGRP production and decreased insulin secretion. Another explanation of the insulin and glucose results in the current experiment could be that insulin sensitivity of insulindependent tissues was increased by RPC and glucose concentration was controlled with less insulin. However, insulin sensitivity was not determined in the current study.

Decreased insulin concentration in cows fed RPC may lower glucose uptake in insulin-dependent tissues such as skeletal muscle and adipose tissue (De Koster and Opsomer, 2013). Spared glucose could be used by an insulin-independent tissue, for example, by the mammary gland for lactose synthesis in cows receiving RPC. This hypothesis is supported by the similar glucose concentration among treatments during GTT and higher milk yield and feed efficiency in RPC cows, although milk lactose yield was only numerically higher for RPC.

Nevertheless, data from studies on the effects of capsaicin on glucose and insulin levels have been conflicting. A single dose of $5 \mathrm{~g}$ of Capsicum frutescens decreased plasma glucose concentration at 30 and 45 min post oral glucose challenge and increased plasma insulin concentration at 60, 75, 105, and $120 \mathrm{~min}$ in a human study (Chaiyasit et al., 2009). Akiba et al. (2004) demonstrated that capsaicin treatment increased insulin released from pancreatic islet $\beta$-cells by

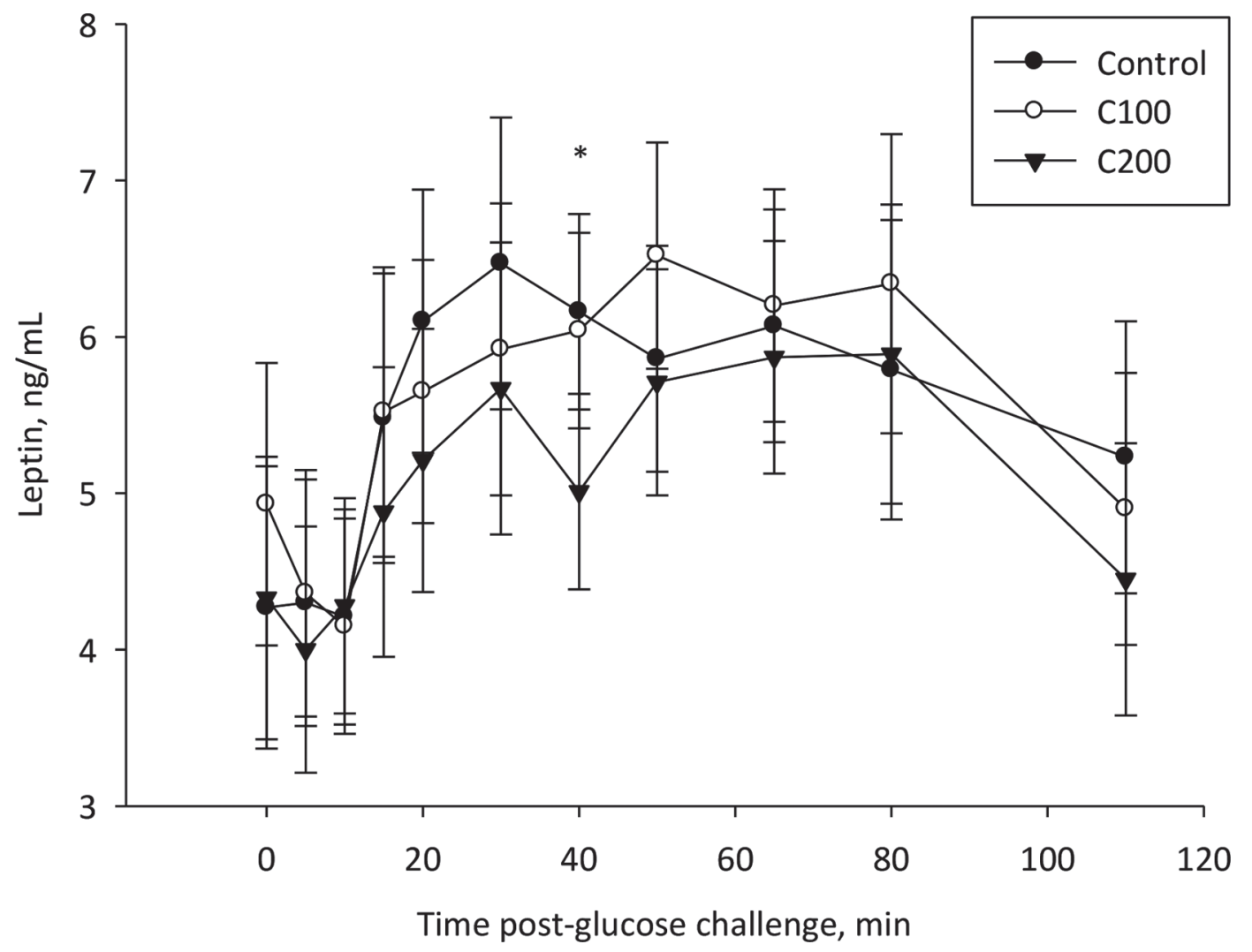

Figure 5. Effect of rumen-protected Capsicum oleoresin (RPC) on serum leptin concentration (mean \pm SE) following intravenous administration of glucose in dairy cows. Control $=0 \mathrm{mg} / \mathrm{d}$ RPC; C100 $=100 \mathrm{mg} / \mathrm{d}$ RPC; C200 $=200 \mathrm{mg} / \mathrm{d}$ RPC. Orthogonal contrast between control and treatments $\left(\mathrm{n}=23 ; \mathrm{n}\right.$ represents number of observations used in the statistical analysis), ${ }^{*} P=0.03$ linear effect. 
increasing $\mathrm{Ca}^{2+}$ influx through the capsaicin receptor expressed on $\beta$ cells. Dömötör et al. (2006) observed increases in serum glucose and glucagon concentration after oral glucose challenges when $400 \mu \mathrm{g}$ of capsaicin was administrated to human subjects, whereas serum insulin was not affected by capsaicin. In dairy cows, we previously observed no effect of Capsicum on insulin concentration in plasma (Oh et al., 2015). However, blood samples were collected only 2 times in $1 \mathrm{~d}$ of each experimental period.

Fat mobilization depends on energy supply in the lactating dairy cow (Drackley et al., 2005). Decreases in NEFA concentration for all treatments after glucose administration were accompanied with increased glucose concentration in the current experiment. Limited effect of RPC on circulating NEFA is also consistent with the glucose results in the current experiment, although we observed subtle increases at 65 and $80 \mathrm{~min}$ post glucose challenge in cows fed RPC. Studies reported that dietary supplementation of capsaicin increased fat mobilization and blood free $\mathrm{FA}$ in rats (Kawada et al., 1986; Yoshioka et al., 2000). According to Lee et al. (2013b), capsaicin increased gene expression of lipoprotein lipase and adiponectin in mesenteric adipose tissues of capsaicin-treated rats, both of which are related to fat accumulation reduction and FA combustion (Yamauchi et al., 2001; Koike et al., 2004). Limited studies exist on the effect of Capsicum on NEFA and BHB in dairy cows. In our previous study, plasma BHB concentration was increased by Capsicum supplementation, but NEFA was not affected. However, we found only numerical increases in BHB concentration with $\mathrm{RPC}$ in the current experiment.

In the current study, increases in serum leptin concentration for all treatments post glucose challenge were likely due to increased insulin concentration. Insulin is known to stimulate leptin synthesis in adipose tissue (Amstalden et al., 2000; Block et al., 2003). In addition, the response in serum leptin to glucose challenge in the current experiment was in the direction opposite that in NEFA concentration. Because the adipose tissue is mainly responsible for leptin concentration in ruminants, fat mobilization could negatively affect leptin concentration (Chilliard et al., 2001). Studies with dairy cows and beef cattle have shown positive correlation between leptin and body fatness (Kokkonen et al., 2005; Foote et al., 2016), which is in agreement with the leptin and NEFA data in the current experiment. We found a time $\times$ treatment interaction in serum leptin when the data were analyzed as repeated measure in the current study. This interaction was caused by highly variable leptin concentration during the 3 experimental periods (data not shown). Thus, although a trend existed for a linear decrease in leptin concentration with RPC, the leptin data have to be interpreted with caution.

\section{CONCLUSIONS}

Dietary supplementation of RPC tended to increase milk production and increased feed efficiency in dairy cows. In addition, RPC decreased serum insulin concentration, but glucose concentration did not change during GTT. Our data suggest that, by decreasing insulin secretion, RPC fed at 100 to $200 \mathrm{mg} / \mathrm{d}$ may have redirected glucose for milk production in lactating dairy cows. Production data from this experiment should be interpreted with caution because of the low number of experimental units, short experimental periods, and the crossover experimental design.

\section{ACKNOWLEDGMENTS}

The authors thank Pancosma S.A. (Geneva, Switzerland) for providing partial financial support for this project and the RPC used in the experiment, Centralized Biological Laboratory (The Pennsylvania State University) for glucose analysis, MR DNA (Molecular Research) for fecal microbial population analysis, and the staffs of The Pennsylvania State University's Dairy Teaching and Research Center for their conscientious care of the experimental cows.

\section{REFERENCES}

Ahuja, K. D., I. K. Robertson, D. P. Geraghty, and M. J. Ball. 2006. Effects of chili consumption on postprandial glucose, insulin, and energy metabolism. Am. J. Clin. Nutr. 84:63-69.

Akiba, Y., S. Kato, K. Katsube, M. Nakamura, K. Takeuchi, H. Ishii, and T. Hibi. 2004. Transient receptor potential vanilloid subfamily 1 expressed in pancreatic islet beta cells modulates insulin secretion in rats. Biochem. Biophys. Res. Commun. 321:219-225.

Amstalden, M., M. R. Garcia, S. W. Williams, R. L. Stanko, S. E. Nizielski, C. D. Morrison, D. H. Keisler, and G. L. Williams. 2000. Leptin gene expression, circulating leptin, and luteinizing hormone pulsatility are acutely responsive to short-term fasting in prepubertal heifers: Relationships to circulating insulin and insulin-like growth factor I(1). Biol. Reprod. 63:127-133.

AOAC International. 2000. Official Methods of Analysis. 17th ed. AOAC International, Arlington, VA.

AOAC International. 2006. Official Methods of Analysis. 18th ed. AOAC International, Arlington, VA.

Archimède, H., D. Sauvant, and P. Schmidely. 1997. Quantitative review of ruminal and total tract digestion of mixed diet organic matter and carbohydrates. Reprod. Nutr. Dev. 37:173-189.

Bell, A. W., and D. E. Bauman. 1997. Adaptations of glucose metabolism during pregnancy and lactation. J. Mammary Gland Biol. Neoplasia 2:265-278.

Block, S. S., R. P. Rhoads, D. E. Bauman, R. A. Ehrhardt, M. A. McGuire, B. A. Crooker, J. M. Griinari, T. R. Mackle, W. J. Weber, M. E. Van Amburgh, and Y. R. Boisclair. 2003. Demonstration of a role for insulin in the regulation of leptin in lactating dairy cows. J. Dairy Sci. 86:3508-3515. 
Burt, S. 2004. Essential oils: Their antibacterial properties and potential applications in foods-a review. Int. J. Food Microbiol. 94:223-253.

Calsamiglia, S., M. Busquet, P. W. Cardozo, L. Castillejos, and A. Ferret. 2007. Invited review: Essential oils as modifiers of rumen microbial fermentation. J. Dairy Sci. 90:2580-2595.

Cardoso, F. C., W. Sears, S. J. LeBlanc, and J. K. Drackley. 2011. Technical note: Comparison of 3 methods for analyzing areas under the curve for glucose and nonesterified fatty acids concentrations following epinephrine challenge in dairy cows. J. Dairy Sci. 94:6111-6115.

Cardozo, P. W., S. Calsamiglia, A. Ferret, and C. Kamel. 2006. Effects of alfalfa extract, anise, capsicum, and a mixture of cinnamaldehyde and eugenol on ruminal fermentation and protein degradation in beef heifers fed a high-concentrate diet. J. Anim. Sci 84:2801-2808

Chaiyasit, K., W. Khovidhunkit, and S. Wittayalertpanya. 2009. Pharmacokinetic and the effect of capsaicin in Capsicum frutescens on decreasing plasma glucose level. J. Med. Assoc. Thai. 92:108-113.

Chen, X. B., Y. K. Chen, M. F. Franklin, E. R. Ørskov, and W. J. Shand. 1992. The effect of feed intake and body weight on purine derivative excretion and microbial protein supply in sheep. J. Anim. Sci. 70:1534-1542.

Chilliard, Y., M. Bonnet, C. Delavaud, Y. Faulconnier, C. Leroux, J. Djiane, and F. Bocquier. 2001. Leptin in ruminants. Gene expression in adipose tissue and mammary gland, and regulation of plasma concentration. Domest. Anim. Endocrinol. 21:271-295.

Cichewicz, R. H., and P. A. Thorpe. 1996. The antimicrobial properties of chile peppers (Capsicum species) and their uses in Mayan medicine. J. Ethnopharmacol. 52:61-70.

De Koster, J. D., and G. Opsomer. 2013. Insulin resistance in dairy cows. Vet. Clin. North Am. Food Anim. Pract. 29:299-322.

Debreceni, A., O. M. Abdel-Salam, M. Figler, I. Juricskay, J. Szolcsányi, and G. Mózsik. 1999. Capsaicin increases gastric emptying rate in healthy human subjects measured by $13 \mathrm{C}$-labeled octanoic acid breath test. J. Physiol. Paris 93:455-460.

Demirbilek, S., M. O. Ersoy, S. Demirbilek, A. Karaman, N. Gürbüz, N. Bayraktar, and M. Bayraktar. 2004. Small-dose capsaicin reduces systemic inflammatory responses in septic rats. Anesth. Analg. 99:1501-1507.

Dömötör, A., J. Szolcsányi, and G. Mózsik. 2006. Capsaicin and glucose absorption and utilization in healthy human subjects. Eur. J. Pharmacol. 534:280-283.

Drackley, J. K., H. M. Dann, G. N. Douglas, N. A. Janovick Guretzky, N. B. Litherland, J. P. Underwood, and J. J. Loor. 2005. Physiological and pathological adaptations in dairy cows that may increase susceptibility to periparturient diseases and disorders. Ital. J. Anim. Sci. 4:323-344.

Fandiño, I., S. Calsamiglia, A. Ferret, and M. Blanch. 2008. Anise and capsicum as alternatives to monensin to modify rumen fermentation in beef heifers fed a high concentrate diet. Anim. Feed Sci. Technol. 145:409-417.

Foote, A. P., R. G. Tait, D. H. Keisler, K. E. Hales, and H. C. Freetly. 2016. Leptin concentrations in finishing beef steers and heifers and their association with dry matter intake, average daily gain, feed efficiency, and body composition. Domest. Anim. Endocrinol. $55: 136-141$.

Hristov, A. N., C. Lee, T. Cassidy, M. Long, B. Corl, and R. Forster 2011. Effects of lauric and myristic acids on ruminal fermentation, production, and milk fatty acid composition in lactating dairy cows. J. Dairy Sci. 94:382-395.

Hsu, C. L., and A. Yen. 2007. Effects of capsaicin on induction of apoptosis and inhibition of adipogenesis in 3T3-L1 cells. J. Agric. Food Chem. 55:1730-1736.

Huhtanen, P., K. Kaustell, and S. Jaakkola. 1994. The use of internal markers to predict total digestibility and duodenal flow of nutrients in cattle given six different diets. Anim. Feed Sci. Technol. 48:211-227.

Kawada, T., K. Hagihara, and K. Iwai. 1986. Effects of capsaicin on lipid metabolism in rats fed a high fat diet. J. Nutr. 116:1272-1278.
Koike, T., J. Liang, X. Wang, T. Ichikawa, M. Shiomi, G. Liu, H. Sun, S. Kitajima, M. Morimoto, T. Watanabe, N. Yamada, and J. Fan. 2004. Overexpression of lipoprotein lipase in transgenic Watanabe heritable hyperlipidemic rabbits improves hyperlipidemia and obesity. J. Biol. Chem. 279:7521-7529.

Kokkonen, T., J. Taponen, T. Anttila, L. Syrjala-Qvist, C. Delavaud, Y. Chilliard, M. Tuori, and A. T. Tesfa. 2005. Effect of body fatness and glucogenic supplement on lipid and protein mobilization and plasma leptin in dairy cows. J. Dairy Sci. 88:1127-1141.

Lee, G. R., M. K. Shin, D. J. Yoon, A. R. Kim, R. Yu, N. H. Park, and I. S. Han. 2013b. Topical application of capsaicin reduces visceral adipose fat by affecting adipokine levels in high-fat diet-induced obese mice. Obesity (Silver Spring) 21:115-122.

Lee, S. H., H. S. Lillehoj, S. I. Jang, E. P. Lillehoj, W. Min, and D. M. Bravo. 2013a. Dietary supplementation of young broiler chickens with Capsicum and turmeric oleoresins increases resistance to necrotic enteritis. Br. J. Nutr. 110:840-847.

Liu, Y., M. Song, T. M. Che, J. J. Lee, D. Bravo, C. W. Maddox, and J. E. Pettigrew. 2014. Dietary plant extracts modulate gene expression profiles in ileal mucosa of weaned pigs after an Escherichia coli infection. J. Anim. Sci. 92:2050-2062.

McCann, M. J., J. G. Verbalis, and E. M. Stricker. 1988. Capsaicin pretreatment attenuates multiple responses to cholecystokinin in rats. J. Auton. Nerv. Syst. 23:265-272.

NRC (National Research Council). 2001. Nutrient Requirements of Dairy Cattle. 7th rev. ed. Natl. Acad. Sci., Washington, DC.

Oetzel, G. R. 2004. Monitoring and testing dairy herds for metabolic disease. Vet. Clin. North Am. Food Anim. Pract. 20:651-674.

Oh, J., M. Harper, F. Giallongo, D. M. Bravo, E. H. Wall, and A. N. Hristov. 2017. Effects of rumen-protected Capsicum oleoresin on immune responses in dairy cows intravenously challenged with lipopolysaccharide. J. Dairy Sci. 100:1902-1913. https://doi. org/10.3168/jds.2016-11666.

Oh, J., A. N. Hristov, F. Giallongo, T. Frederick, J. Pate, S. Walusimbi, R. J. Elias, E. H. Wall, and D. Bravo. 2015. Effects of dietary Capsicum oleoresin on productivity and immune responses in lactating dairy cows. J. Dairy Sci. 98:6327-6339.

Oh, J., A. N. Hristov, C. Lee, T. Cassidy, K. Heyler, G. A. Varga, J. Pate, S. Walusimbi, E. Brzezicka, K. Toyokawa, J. Werner, S. S. Donkin, R. Elias, S. Dowd, and D. Bravo. 2013. Immune and production responses of dairy cows to postruminal supplementation with phytonutrients. J. Dairy Sci. 96:7830-7843

Pettersson, M., and B. Ahrén. 1990. Calcitonin gene-related peptide inhibits insulin secretion studies on ion fluxes and cyclic AMP in isolated rat islets. Diabetes Res. 15:9-14.

Pires, J. A. A., A. H. Souza, and R. R. Grummer. 2007. Induction of hyperlipidemia by intravenous infusion of tallow emulsion causes insulin resistance in Holstein cows. J. Dairy Sci. 90:2735-2744.

Platel, K., and K. Srinivasan. 1996. Influence of dietary spices or their active principles on digestive enzymes of small intestinal mucosa in rats. Int. J. Food Sci. Nutr. 47:55-59.

Platel, K., and K. Srinivasan. 2000. Influence of dietary spices and their active principles on pancreatic digestive enzymes in albino rats. Nahrung 44:42-46.

Ramakrishna Rao, R., K. Platel, and K. Srinivasan. 2003. In vitro influence of spices and spice-active principles on digestive enzymes of rat pancreas and small intestine. Nahrung 47:408-412.

Rodríguez-Prado, M., A. Ferret, J. Zwieten, L. Gonzalez, D. Bravo, and S. Calsamiglia. 2012. Effects of dietary addition of capsicum extract on intake, water consumption, and rumen fermentation of fattening heifers fed a high-concentrate diet. J. Anim. Sci. 90:1879-1884

Sjaunja, L. O., L. Baevre, L. Junkkarinen, J. Pedersen, and J. Setälä. 1990. A Nordic proposal for an energy corrected milk (ECM) formula. In 27th Session of the International Commission for Breeding and Productivity of Milk Animals, Paris, France. Wageningen Academic Publishers, Wageningen, the Netherlands.

Srinivasan, K. 2016. Biological activities of red pepper (Capsicum annuum) and its pungent principle capsaicin: A review. Crit. Rev. Food Sci. Nutr. 56:1488-1500. 
Tager, L. R., and K. M. Krause. 2011. Effects of essential oils on rumen fermentation, milk production, and feeding behavior in lactating dairy cows. J. Dairy Sci. 94:2455-2464.

Tanaka, H., R. Kashiwagi, and T. Koizumi. 2013. Inhibition of calcitonin gene-related peptide (CGRP) has the potential to extend first-phase insulin secretion. Exp. Clin. Endocrinol. Diabetes 121:280-285.

van de Wall, E. H., D. X. Gram, J. H. Strubbe, A. J. Scheurink, and J. M. Koolhaas. 2005. Ablation of capsaicin-sensitive afferent nerves affects insulin response during an intravenous glucose tolerance test. Life Sci. 77:1283-1292.

van de Wall, E. H., P. Y. Wielinga, J. H. Strubbe, and G. van Dijk. 2006. Neonatal capsaicin causes compensatory adjustments to energy homeostasis in rats. Physiol. Behav. 89:115-121.

van Oosterhout, W. P., G. G. Schoonman, I. M. Garrelds, A. H. Danser, K. Y. Chan, G. M. Terwindt, M. D. Ferrari, and A. MaassenVanDenBrink. 2015. A human capsaicin model to quantitatively assess salivary CGRP secretion. Cephalalgia 35:675-682.
Van Soest, P. J., J. B. Robertson, and B. A. Lewis. 1991. Methods for dietary fiber, neutral detergent fiber, and nonstarch polysaccharides in relation to animal nutrition. J. Dairy Sci. 74:3583-3597.

Yamauchi, T., J. Kamon, H. Waki, Y. Terauchi, N. Kubota, K. Hara, Y. Mori, T. Ide, K. Murakami, N. Tsuboyama-Kasaoka, O. Ezaki, Y. Akanuma, O. Gavrilova, C. Vinson, M. L. Reitman, H. Kagechika, K. Shudo, M. Yoda, Y. Nakano, K. Tobe, R. Nagai, S. Kimura, M. Tomita, P. Froguel, and T. Kadowaki. 2001. The fatderived hormone adiponectin reverses insulin resistance associated with both lipoatrophy and obesity. Nat. Med. 7:941-946.

Yoshioka, M., M. Tatsuhiro, K. Lim, A. Tremblay, and M. Suzuki. 2000. Effects of capsaicin on abdominal fat and serum free-fatty acids in exercise-trained rats. Nutr. Res. 20:1041-1045.

Zachut, M., H. Honig, S. Striem, Y. Zich, S. Boura-Halfon, and U. Moallem. 2013. Periparturient dairy cows do not exhibit hepatic insulin resistance, yet adipose-specific insulin resistance occurs in cows prone to high weight loss. J. Dairy Sci. 96:5656-5669. 